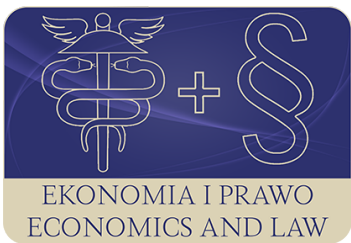

EKONOMIA I PRAWO. ECONOMICS AND LAW

Volume 18, Issue 2, June 2019

p-ISSN 1898-2255, e-ISSN 2392-1625

www.economicsandlaw.pl

EKONOMIA I PRAWO
ECONOMICS AND LAW

ORIGINAL ARTICLE

received 28.09.2018; revised 29.06.2019; accepted 30.06.2019

Citation: Madrak-Grochowska, M. (2019). Jerzy Tomala: economist of growth and development.

Ekonomia i Prawo. Economics and Law, 18(2): 209-232.

doi:10.12775/EiP.2019.016.

\title{
Jerzy Tomala: economist of growth and development
}

\author{
MAEGORZATA MADRAK-GROCHOWSKA \\ Nicolaus Copernicus University in Toruń, Faculty of Economic Sciences and Management, \\ Department of Economics, ul. Gagarina 13a, 87-100 Toruń, Poland \\ $\square$ madrak_grochowska@umk.pl \\ (iD) orcid.org/0000-0001-5687-7360
}

\begin{abstract}
Motivation: The year 2018 was celebrated at the Faculty of Economic Sciences and Management of Nicolaus Copernicus University in Torun, Poland as the 50th anniversary of the existence of the Faculty. To celebrate this jubilee, numerous conferences, debates, conventions and occasional meetings were organized. On the occasion of these events, people who contributed greatly to the development of the Faculty of Economic Sciences and Management in the area of science and didactics as well as in the organizational field were recalled and honoured. Undoubtedly, Professor Jerzy Tomala was one of them. Aim: The aim of this article is to present the biography of Professor Jerzy Tomala with special emphasis on his scientific accomplishments, international successes, as well as didactic and organizational achievements at the Faculty of Economic Sciences and Management of Nicolaus Copernicus University in Torun, Poland.

Results: During many years of his scientific work, Professor Jerzy Tomala became a scholar who was recognised both in Poland and internationally - first and foremost as an authority in the field of broadly understood macroeconomic problems of economic growth (with particular emphasis laid on the impact of investment, technological progress and efficiency of technical and economic relations on the long-term growth of national income) and in the area of economic policy of developed countries, mainly of the United States of America. His scientific interests also included the issue of full employment, the concept of a potential national product and educational policy. Professor Jerzy Tomala was invited

to various study internships at renowned universities in the United States and to renowned scientific and teaching institutions in Western Europe. He also worked as a consultant of the World Bank, and his publications impacted some important decisions made by international organizations such as, for instance, OECD, the European Community, or
\end{abstract}


the World Bank. For his achievements in the field of science, didactics and organizational work, Professor Jerzy Tomala received high state awards, prestigious awards of the Minister of Higher Education and the Rector of Nicolaus Copernicus University in Torun, as well as numerous honours from his students and alumni.

Keywords: history of economic thought; economic growth and development; economic policies of developed countries

JEL: B31; O00; O20

\section{Introduction}

A great scientific talent, an internationally recognized economist, a respected academic teacher and activist supporting Nicolaus Copernicus University in Torun - these are probably the best epithets describing the outstanding figure of Professor Jerzy Tomala. In his research activity, Professor Jerzy Tomala focused primarily on the macroeconomic problems of economic growth and development (with particular emphasis laid on the impact of investment, technological progress and efficiency of technical and economic relations on the long-term growth of national income) and the economic policy of developed countries, mainly of the United States. His scientific interests also covered the issue of full employment, the concept of a potential national product and educational policy. As the first in the Polish economic literature, he provided a comprehensive analysis of the Denison's multi-factor model. The Professor was invited to various study internships at prominent universities in the United States and to renowned scientific and teaching institutions in Western Europe, where he participated in numerous debates on the main problems of the global economy and the role of economic education in socio-economic development. He also worked as a visiting professor in some higher education institutions. Professor Jerzy Tomala was also a consultant of the World Bank, and his publications impacted some important decisions made by international organizations such as, for instance, OECD, the European Community, or the World Bank. For his accomplishments in the fields of science, didactics and organizational work, Professor Jerzy Tomala received high state awards, prestigious awards of the Minister of Higher Education and the Rector of Nicolaus Copernicus University in Toruń, as well as numerous honours from his students and alumni.

\section{Methods}

This article is an academic biography of Professor Jerzy Tomala and a review based on both primary sources (mainly the Professor's personal files and publications of his authorship or co-authorship) and secondary sources (primarily biographical notes previously written about the Professor as well as memoirs of his colleagues and students). 


\section{First steps}

Jerzy Alfons Robert Tomala was born on April 6, 1926 in the town of Bierun Stary, in the Pszczyna district ${ }^{1}$, as the son of Alfons and Franciszka née Kołoch. In this small town in Upper Silesia, Poland, his parents - refugees after the third Silesian Uprising — found asylum, and Jerzy Tomala spent there the first years of his life (Tomala, n.d.).

As a seven-year-old boy, in September of 1933, he started attending the elementary school in Bierun Stary, which he graduated in 1939. However, his carefree childhood was interrupted by the outbreak of the Second World War. Jerzy Tomala spent the period of the Nazi occupation in the town of Bytom that is situated forty-one kilometres away from the town of Bierun Stary, where in 1941-1944 he studied at a private secondary school and worked in the Neugebauer trading company. At the end of 1944, adult Jerzy Tomala managed to get through Germany and France to the American side and as a volunteer he joined the American motorized army, and from April 1945 he performed the function of an interpreter at $4225^{\text {th }}$ Polish Service Co. After the war, in August 1946, he returned to Poland (Karaszewski, 2004, p. 9; Tomala, n.d.).

In September of 1946 Jerzy Tomala resumed his education, which was interrupted during the war, at the State Junior High School and Secondary School in Katowice, where in 1948 he passed the secondary school-leaving examination. In the same year, he moved out to the city of Poznań and there he began studying at the Higher School of Economics, the Faculty of Finance (Karaszewski, 2004, p. 9).

\section{The beginnings of Jerzy Tomala's scientific career}

On September 1, 1951, Jerzy Tomala - still a third year student at the Higher School of Economics in Poznań - took up a job as a deputy assistant at the Department of Planning and Economic Policy, headed by the late Professor Seweryn Kruszczyński. In 1953 he graduated the school and obtained a master's degree in economics with a very good grade, specialisation in the field of planning the national economy. He defended his master's thesis entitled Tempo wzrostu produkcji przemystowej na przyktadzie Niemieckiej Republiki Demokratycznej (The pace of industrial production growth based on the example of the German Democratic Republic), in which he analysed the factors of rapid production growth in the then German Democratic Republic and drew conclusions for planning the national economy, enriching his arguments with practical numerical material. After obtaining the title of Master of Economics, in the years 1953-1969 Jerzy Tomala performed the functions of assistant, senior assistant, adjunct and associate professor successively in the above-mentioned Department

${ }^{1}$ Currently, Bieruń is a town and an urban commune in the bieruński-lędziński district of the śląskie province. 
of Planning and Economic Policy of the Higher School of Economics in Poznań (Tomala, n.d.) ${ }^{2}$.

In the years 1954-1956, the main source of Jerzy Tomala's scientific interests were in-depth studies in the field of economic policy, planning, and Western economic theory, which he continued under the direction of the late Professor Seweryn Kruszczyński. In this period, the young assistant published two articles, i.e. Znaczenie i drogi wzrostu wydajności pracy (The importance and ways of increasing labour productivity) (Tomala, 1954a) and Znaczenie lepszego wykorzystania zdolności produkcyjnych przedsiębiorstw dla wzrostu dobrobytu spoteczeństwa (The importance of better use of production capacities of enterprises to increase the well-being of society) (Tomala, 1954b), published in the Gazeta Poznanska in the early 1954.

At the same time, Jerzy Tomala joined a team research programme which was being implemented then in the structures of the Department of Planning and Economic Policy of the Higher School of Economics in Poznan and whose main goal was to analyse the factors of production growth and national income. The task that was assigned to him within this project was to conduct research on the development of industrial production in the then Federal Republic of Germany and the German Democratic Republic (Jaworowski, 1993, p. 195). Jerzy Tomala presented the first results of his analyses in the article titled Bilans dziesięciolecia budownictwa pokojowej gospodarki na terenie Niemieckiej Republiki Demokratycznej (1945-1955) (The balance of the decade of peaceful economy construction in the German Democratic Republic (1945-1955)) which was published in the Przegląd Zachodni magazine in 1955. In this work, he described the process of democratization of the economy and social life, which took place during the post-war decade in East Germany. Particular emphasis was put on the implementation of a two-year plan and five-year plan for the reconstruction and development of the national economy, planned construction of the foundations of socialism, as well as on the so-called 'new-course' policy. The transformation was shown at the same time through the prism of changes being introduced in the then German Democratic Republic, i.e. through the nationalization of banks and the insurance system, agricultural and industrial reform, creation of state wholesale and retail trade, and the creation of socialized transport. Moreover, he enriched his work with an extremely extensive numerical material (Tomala, 1955, pp. 430-454). The continuation of these considerations was published in an article entitled O proporcjach $w$ rozwoju produkcji przemystowej $w$ Niemieckiej Republice Demokratycznej (Proportions in the development of industrial production in the German Democratic Republic) published in 1956 by the Przeglad Zachodni magazine. In this study, Jerzy Tomala put forward the thesis that one of the most important conditions for the effectiveness of economic policy

2 In the years 1952-1953 Jerzy Tomala performed the function of deputy assistant, in 1953-1955 of assistant, in 1955-1968 of senior assistant, in 1968-1969 - of assistant professor at the Department of Planning and Economic Policy of the Higher School of Economics in Poznań. 
is to provide the right proportions in the development of individual branches of production, both sections of social production (i.e. Sections I and II) and of all spheres of the social process of expanded reproduction (i.e. production, distribution, exchange, and consumption), and thus the distribution of means of production and workforce across the sectors of material production (Tomala, 1956, pp. 86-117). The crowning of this research was a book written by Jerzy Tomala titled Tempo rozwoju produkcji przemystowej w Niemieckiej Republice Demokratycznej (The pace of industrial production development in the German Democratic Republic), published in 1957 by the Western Institute. In this publication, based on the results of his empirical analysis of the proportion of industrial production development in the then German Democratic Republic, the author formulated general conditions defining an acceptable range between the growth rate of social production in Sections I and II and in industrial Groups A and B (Tomala, 1957).

In the years 1957-1961 Jerzy Tomala focused his research and scientific efforts on the broadly understood issues of economic growth, showing special interest in the issues of the impact of investment, technological progress and efficiency of technical and economic relations on the long-term growth of national income (Polszakiewicz, 2006, p. 15). During this time, in the pages of Journal of Law, Economics and Socjology, he published an article entitled Technologiczne parametry wzrostu produkcji (Technological parameters of production growth), in which he initiated an active scientific debate on the concept and measures of technological progress and the size of employment and labour productivity, and their role in economic growth (Tomala, 1960, pp. 125-147). The complementation and expansion of these arguments was the publication (in 1961) of Kwantyfikacja wptywu zmian zatrudnienia i wydajności pracy na proces wzrostu gospodarczego (Quantification of the impact of changes in employment and labour productivity on the process of economic growth), in which Jerzy Tomala first analysed the relationship between the increase in national income and the amount and efficiency of live work, and secondly, the correlation between national income growth and fixed capital. In addition, in the work he combined direct and indirect factors of economic growth into one formula, thus presenting a dynamic balance of full employment of existing living resources. As followed from this equation, a given growth rate of labour supply and the desired rate of growth of national income, the parameters of its balanced dynamics are primarily the savings rate equal to the investment rate, the labour productivity growth rate and the marginal capital ratio, and the planning of specific, interrelated levels of these parameters constitute one of the essential conditions for an effective policy of economic growth (Tomala, 1961b, pp. 113-127). The continuation of these reflections was a review by Jerzy Tomala of the publication of Krzysztof Wandelt entitled Istota i rodzaje postępu technicznego (The essence and types of technological progress), published in 1961 in The Economic Yearbook of the PTE Branch in Poznan 1960' (Tomala, 1961a, pp. 234-247). 
The crowning achievement of the research on the problems of economic and technical relations between fixed capital and investments and the level and growth of national income was the doctoral dissertation entitled Relacje kapitatowe $w$ teorii wzrostu gospodarczego (Capital relations in the theory of economic growth), written under the direction of the late Professor Seweryn Kruszczyński. On May 31, 1961, on the basis of this dissertation, Jerzy Tomala obtained the academic degree of doctor of economic sciences, granted to him by the resolution of the Council of the Faculty of Economics at the Higher School of Economics in Poznań. In 1963, this work was published by Panstwowe Wydawnictwo Naukowe (the State Scientific Publisher) and awarded with the third degree academic award of the Minister of Higher Education, and then translated into Czech for the internal needs of the Institute of Economics of the Czechoslovakian Academy of Sciences (Jaworowski, 1999, p. 188; Polszakiewicz, 2006, p. 15; Tomala, n.d.). In his doctoral dissertation, Jerzy Tomala conducted an analysis of capital relations based on Western models of economic growth, including also the models of Professors Oskar Lange and Michał Kalecki. As emphasized by the reviewers of the work, the author brought to the theory of economic growth many original approaches and valuable insights into the area of sustainable growth, dynamic growth rate of full employment and the growth rate of full use of production fixed assets. Additionally, based on the analyses presented in the doctoral dissertation, Jerzy Tomala formulated the equation of optimal dynamic balance, indicating at the same time that the technical-economic relations necessary to achieve this balance are not obtained automatically. Thus, he drew attention to the necessity of using intervening economic policy of the state in highly developed capitalist countries to achieve sustainable economic growth (Tomala, 1963). This work was recognized by experts on the subject as an outstanding analysis of the economic and technical relationships between fixed assets and investments and the increase in national income, and became the starting point for a whole range of research activities conducted by Jerzy Tomala in the later period of his scientific activity (Tomala, n.d.).

In the years 1961-1965 - already being a doctor of economic sciences Jerzy Tomala continued to explore the issues of economic growth and in recognized scientific journals such as, for instance, Ekonomista, Journal of Law, Economics and Sociology, or Scientific Notebooks of the Higher School of Economics in Poznań, he actively participated in a lively debate on this topic. During this period, he was mainly fascinated with economic growth models of contemporary Western economic theory, including in particular the Harrod-Domar models and the embedded in them growth-generating mechanisms in the form of induced and autonomous investments, as well as those concerning the combination of investment multiplier and the acceleration principle (Polszakiewicz, 2006, p. 15). Moreover, by accepting the separation of induced and autonomous investments as a useful analytical instrument for the growth processes of the market economy, Jerzy Tomala, Ph.D proved the heterogeneous nature of autonomous investments and considered unrealistic referring acceleration 
only and exclusively to those induced investments that extensively increase fixed capital. Nor did he consider it reasonable to identify the accelerator with a capital ratio, as Professor Roy Forbes Harrod did (Jaworowski, 1999, p. 189). Numerous articles written by Doctor Jerzy Tomala and published in 1962 were a permanent trace of these deliberations and scientific discussions.

One of them was a study entitled O przyspieszeniu, inwestycjach indukowanych $i$ autonomicznych (Acceleration, induced and autonomous investments), published in the Journal of Law, Economics and Sociology. In this work, Jerzy Tomala, Ph.D. claimed that the postulated growth rate of consumption (with the desired technical conditions of production and a given production structure) requires a specific growth rate of fixed assets, which determines the acceleration coefficient. The considerations carried out also showed that achieving the desired pace of economic growth (for which, for example, a specific rate of investment growth is necessary) requires an appropriate dynamics of consumption growth. In turn, according to the author, the relations that were described determined to a large extent a set of conditions influencing the dynamic balance of the national economy and, therefore, should be included in the theory of economic growth (Tomala, 1962c, pp. 139-160).

Another high-profile article (1962) by Jerzy Tomala, which focused on the issue of the growth of national income was Postęp techniczny i wzrost gospodarczy (Technological progress and economic growth) published in the Ekonomista journal. In this publication the problem of technological progress was considered with a significant limitation of the subject of research, i.e. only and exclusively within the quantitative economic analysis of technological progress carried out from the point of view of three types of technological progress: capital-intensive (or labour-saving) technological, neutral, and capital-saving (i.e. labour-intensive) progress. At the same time, this article contributed to the considerations on both the development of the long-term trend of the macroeconomic capital ratio and the selection of more or less capital-intensive directions in investment policy. In addition, in this work Jerzy Tomala emphasized the inevitable exploration of interdependencies between capital intensity, labour productivity and capital ratio, and perceived the need for disaggregation of macroeconomic variables, including material and technical aspects of acceleration as well as other factors (Tomala, 1962d, pp. 66-87).

Some of these problems were included in Jerzy Tomala's further research, the results of which were published in the same year in an article entitled Dtugofalowy trend wspótczynnika kapitatu (Long-term trend of the capital ratio). In this study, the author argued that the formation of the empirical macroeconomic capital ratio is primarily influenced by such factors as technological progress, changes in labour productivity, volume of investment outlays, structural changes in production and directions of investment outlays, the degree of the use of existing production capacities, material structure of the investment, natural and geographical conditions, and the period of construction of production facilities. Moreover, he proved that the economic growth of capitalist industrialized 
countries is - despite the occurrence of depression phases and crises - much higher than the economic growth recorded in the backward capitalist countries in which the process of industrialization is absent. On these grounds, the author concluded that the concentration of investments on the relatively more capital-intensive technology, with the initial relatively high capital-output coefficients of production, ensures a higher rate of economic growth in the long run compared to the concentration of investments on the relatively less capital-intensive technology, which results from the decisive influence of technological progress on growth of social labour productivity (Tomala, 1962a, pp. 1392-1406).

At the same time, two more publications by Jerzy Tomala, discussing the issues of technological progress and growth, were published. These were Koncepcja równowagi dynamicznej $w$ modelach wzrostu typu Harrod-Domar (The concept of dynamic equilibrium in the Harrod-Domar-type growth models) (Tomala, 1962b, pp. 41-76) and the review of the habilitation thesis written by Jerzy Lisikiewicz entitled Postęp techniczny a wydajność pracy w przemyśle (Technological progress and labour productivity in industry) (Tomala, 1964, pp. 629-633).

At this point, it should also be mentioned that in the time period 1961-1965, in parallel with his scientific publications, a collective work - Polityka ekonomiczna i planowanie gospodarki narodowej (Economic policy and national economy planning) - in which Jerzy Tomala was one of four co-authors (Dąbrowski et al., 1961; 1962; 1965) came out three times in the form of university scripts.

\section{The flourishing of the scientific career}

In the years 1966-1967, Jerzy Tomala, Ph.D. went on a research internship to the United States of America, which he held at the University of California at Berkeley and at the Brookings Institution in Washington. He used that time extremely fruitfully, actively participating in numerous scientific discussions devoted to the main problems of the global economy and the role of economic education in the socio-economic development of countries. During this period, when being invited to various scientific and didactic institutions, he delivered a number of lectures including The role of investment in the development of the Polish Economy (in February 1966 at a scientific session organized by Professor Gregory Grossmann from the University of California at Berkeley), Development and structure of Poland's higher education (in April 1966 at Far West Fulbright Conference w Claremont Graduate School and University Centre, during which he chaired a panel discussion on 'Education and Full Employment') and The role of the international exchange of persons in the development of science and education (presented in September 1966 at an international scientific symposium organized by Columbia University in New York with the motto: 'Diversity and interdependence through international education') (Jaworowski, 1999, p. 189; Polszakiewicz, 2006, p. 16; Tomala, n.d.). Also, at that time two other works were published in Poland, of which he was the author and co-author: 
Dyskusja (Discussion) (Tomala, 1966, pp. 196-199) and the subsequent edition of the script entitled Polityka ekonomiczna i planowanie gospodarki narodowej (Economic policy and national economy planning) (Dąbrowski et al., 1966).

Jerzy Tomala, Ph.D. also (or perhaps first and foremost) devoted his stay in the United States to in-depth studies of the previously considered problems of economic growth, thus he prepared to writing his habilitation thesis entitled Podstawy polityki wzrostu gospodarczego Stanów Zjednoczonych Ameryki Pótnocnej (Fundamentals of the US economic growth policy), based on which in 1968 the Council of the Faculty of Economics of the Higher School of Economics in Poznan awarded to him the academic degree of associate professor in economic sciences in the field of planning and economic policy. In the same year, the habilitation dissertation was published by the Publishing House of the Higher School of Economics in Poznan, and a year later it was awarded the third level scientific award of the Minister of Education and Higher Education (Tomala, n.d.). In this work, Jerzy Tomala, Ph.D. presented the evolution of the goals of the official US economic policy, with particular emphasis laid on economic growth. He concentrated on researching and describing complementary, competitive and conflict-related relationships between these goals, and also attempted to analyse the internal and external causes that led the issue of economic growth to the rank of one of the main goals of the American government's economic policy. With extreme accuracy, he devoted himself to a comprehensive analysis of the elements and criteria of the economic growth policy, thus submitting as the first in Polish economic literature - a comprehensive and thorough assessment of the famous Denison's multifactor model. Furthermore, Jerzy Tomala, Ph.D. in his habilitation thesis criticized purely Keynesian countercyclical state interventionism, claiming that the economic policy based on it is conducted from case to case, i.e. from the deflation gap to the inflation gap (Jaworowski, 1999, p. 190; Karaszewski, 2004, p. 10; Polszakiewicz, 2006, p. 16). At the same time, one of the main hypotheses proposed by him in the work was the following statement: 'short-term intervention entails introducing elements of long-term policy and, consequently, tying countercyclical policy with long-term plans and active policy aimed at achieving the desired rate of economic growth' (Karaszewski, 2004, p. 10), which occurred primarily during the presidency of John Fitzgerald Kennedy. This meant that countercyclical policy itself — in the opinion of Jerzy Tomala — should not be rejected, but that it must become more active, i.e. it would have to be transformed as part of a longterm policy of economic growth from the post factum policy towards countercyclical policy, conducted in the sense of prospective prevention (Jaworowski, 1999, p. 190). This position was also adopted later by the OECD. In addition, the dissertation also emphasized the view that in highly developed countries without an appropriate demand policy, an effective growth policy cannot be pursued (Tomala, 1968).

Shortly after the obtainment of the degree of associate professor of economic sciences, Jerzy Tomala finished the so-called the 'Poznań period' of his 
life and scientific career, and started the so-called the 'Toruń period'. It happened under the decision of the Minister of Education and Higher Education of January 15, 1969, on the basis of which on February 1, 1969 Jerzy Tomala was transferred from the Higher School of Economics in Poznan to Nicolaus Copernicus University in Torun, to the position of a full-time associate professor in the newly founded Institute of Economics ${ }^{3}$. It should be clearly emphasized that he was sent to the University in Torun not only as a scientific authority, but also to complete a teaching and organizational mission. Further three publications that were published in 1970, can be treated as a kind of the Professor's farewell to Poznań. The first of them was an article written to honour his mentor and tutor and was entitled Trzydziestolecie pracy naukowej prof. dr. Seweryna Kruszczyńskiego (Thirty years of scientific work of Professor Seweryn Kruszczyński) (Tomala, 1970b, pp. 65-71). The second publication was the re-published script Polityka ekonomiczna i planowanie gospodarki narodowej (Economic policy and national economy planning) (Kruszczyński et al., 1970), and the last one was a review of Bronisław Miszewski's paper: Postęp ekonomiczny w gospodarce przemystowej (Economic progress in industrial economy) (Tomala, 1970a, pp. 177-181).

In August 1973, Professor Jerzy Tomala went to the Brookings Institution in Washington and Princeton University for the second time for a one-year research internship, where he conducted extensive theoretical studies and conducted in-depth empirical research on the American government's economic policy, including, in particular, educational policy and full employment. His subsequent stay abroad again abounded in numerous scientific papers, mainly in the field of economic growth, given in respectable economic forums. Let us mention some of them: 'Mainsprings of Poland's post-war economic development' (presented in September 1973 at the conference of American economists in Washington), 'Basic proportions of Poland's economic growth' (delivered in November 1973 at the Brookings Scientific Symposium in Brookings Institution in Washington), 'Economic aspects of Poland's education development' (presented in January 1974 at a scientific symposium organized by the Institute for Policy Studies in Washington) and 'The causes and consequences of the US energy crisis' (delivered in March 1974 at the a scientific symposium organized again by the Institute for Policy Studies, during which he presided over one of the panel discussions) (Jaworowski, 1993, pp. 197-198).

Papers delivered at that time increased his popularity in scientific circles and in the beginning of 1974 the Professor received a very prestigious proposal. After the aforementioned scientific symposium, held in January 1974 at the Institute for Policy Studies, Professor Martin Carnoy from Stanford University

3 In 1976, the already-mentioned Economic Institute of Nicolaus Copernicus University in Torun - by virtue of the decision of the Minister of Science, Higher Education and Technology - was transformed into the Faculty of Economic Sciences. In turn, seventeen years later, i.e. in January 1993, the Faculty - by the decision of the Senate of Nicolaus Copernicus University in Torun - changed its name to the Faculty of Economic Sciences and Management and it has been functioning under that name until now. 
invited Professor Jerzy Tomala to participate in the World Bank's planned study on the role of education in economic development. Professor Jerzy Tomala accepted this invitation enthusiastically treating it as a great distinction and at the same time a challenge in his academic career. For this reason, in the years 1974-1975 — as a consultant of the World Bank — he was working on his part of the team study. The most important result of the work of Professor Jerzy Tomala performed within the World Bank project was a study titled Access to higher education in Poland under the aspects of social equality and economic development, the first version of which - with the approval of the World Bank was published in January 1976 by the Publishing House of Nicolaus Copernicus University in Torun (Jaworowski, 1993, p. 198; Karaszewski, 2004, p. 11). In this work, the authors presented the development of Polish education in the social, economic and political context, both during the interwar period and also in the post-war period, i.e. in the years 1945-1975. A special value of this study was the richness of quantitative and qualitative data collected, processed and analysed by researchers, characterizing the Polish higher education system from the point of view of the criteria including student's background (rural area/urban area), social selection, parental influence, vocational orientation, the introduction of examinations qualifications and teaching standards, the quality and effectiveness of education, the offer of educational programmes, the amount and availability of scholarships and other forms of material support for students, the institutional proximity of a university, education costs, as well as educational mobility. In turn, the main conclusion resulting from this study was the highlighting of the interdependencies that occur between social and economic development and assigning higher education the basic role in shaping the general culture of the nation, satisfying individual aspirations and in properly using the achievements of science and technology (Tomala et al., 1976).

Continuing work under the aforementioned World Bank project, in March 1976 Professor Jerzy Tomala participated in a two-week symposium organized by the World Bank in Washington, during which he gave a lecture entitled 'Education Foundation of Poland's Economic Development'. In the second part of this meeting - a typically working one, which was devoted to discussing all of the studies included in the completed collective work - Professor Tomala was the main reviewer of two case studies concerning Cuba and the then Soviet Union. It is worth emphasizing that at the session the Polish study received a high note from its main reviewers, i.e. from Professors Samuel Bowles and Martin Carnoy (Jaworowski, 1993, p. 198; Karaszewski, 2004, p. 11).

The problem of the role of the education system in socio-economic development was also discussed in two other works written during this period, i.e. a study entitled 'Economic and social aspects of higher education in Poland' (Tomala, n.d.) and an extensive article published in The Economist entitled Krytyczna analiza kapitalistycznego systemu oświaty i jego roli w rozwoju spoteczno-gospodarczym (Critical analysis of the capitalist education system and its role in socio-economic development). In the second of these studies, Professor Jerzy 
Tomala presented numerous achievements of the United States in the development of the education system, focusing primarily on the role of popularizing free public education in primary and secondary schools and increasing the accessibility of higher education to lower social classes in the process of scientific and technological progress. At the same time, he drew attention to the crisis of American education, which took place in the 1960s and which was also noticed in particular by theoreticians of education and practicing teachers. In this context, Professor Jerzy Tomala presented the opinions of various educational reformers who proposed numerous modernizations and experiments aimed at improving the then American system of education and training. He also proposed adapting it to new economic and technical conditions which required an increasing number of well-educated people. In this article, a lot of space was also devoted to the presentation of the views of radical critics of the capitalist education system belonging to the so-called the 'detraining of the society' movement, who saw in the prevailing education system a grim institution, organized for the convenience of representatives of state interests, administrators and teachers, and not for the needs of learning people. Within this trend, the Professor focused primarily on presenting the position of Professor Martin Carnoy and his book Education as cultural imperialism, in which, based on historical examples, the central role of education in the crisis of capitalist society was pointed to (Tomala, 1975b, pp. 883-904).

In the late 1970s (due to the change of the US economic policy strategy from the cyclical-corrective orientation towards growth orientation), the scientific interests of Professor Jerzy Tomala focused primarily on the concept of a potential national product and on the issue of full employment. The work Analityczno-instrumentalna rola potencjalnego produktu narodowego (Analytical and instrumental role of a potential national product), published in 1975 in The Economist, was the fruit of reflection on the first of the above-mentioned topics. In this work, the Professor presented and interpreted the role of the potential national product together with its derivatives in the form of potential economic growth and production gap, responding critically to the way in which certain elements of this concept are approached. In the quantification of the potential national product, he saw both indicators for economic policy and the criterion for assessing the effectiveness of this policy. Moreover, he argued that the larger the production gap between the actual and the potential national product, the more economic losses and the lower effectiveness of economic policy (Jaworowski, 1999, p. 191; Tomala, 1975a, pp. 1261-1276). In turn, the result of the research carried out by the Professor on the concept of full employment was an article from 1975 entitled Interpretacja petnego zatrudnienia w powojennej polityce ekonomicznej Stanów Zjednoczonych (Interpretation of full employment in the post-war economic policy of the United States), in which he undertook to analyse and evaluate views on the principle of full employment, as well as the US post-war policy in the implementation of this principle. The author emphasized in this work the necessity of quantifying the goal of full employment, analysing its various 
definitions and presenting the process of implementing the Employment Act of 1946 by successive post-war American governments (Polszakiewicz, 2006, p. 17; Tomala, 1975c, pp. 187-202).

A kind of the coping stone of twenty-seven years of scientific work was the appointment of Professor Jerzy Tomala on July 6, 1978 to the position of university professor at Nicolaus Copernicus University in Toruń (Tomala, n.d.).

Professor Jerzy Tomala's activity in the 1980s was marked by his engagement in the international scientific community, the result of which were the contacts and extended cooperation with West European universities, in particular with universities in Aix-en-Provence, Bamberg, Bochum, Munich, and Oldenburg. In the years 1985-1989, the Professor was often invited for international conferences and scientific symposia, during which he gave numerous lectures and prepared various reports. His most important speeches from that period include Chancen des Osthandels mit Polen nach der polnischen Wirtschaftsreform (presented in May 1985 as the main lecture at the scientific session organized by the Arbeitskreis für Wirtschaft und Verwaltung in Kulmbach), Supply-side economics and economic policy (delivered in June 1985 at the scientific symposium organized by the Universität Freiburg), Bereich und Ziele der polnischen Wirtschaftsreform (presented in August 1985 at a scientific conference organized by Universität Bamberg), Joint Ventures in Polen (presented in May 1986 at the German-Hungarian scientific symposium organized by the Universität Bamberg), Die Notwendigkeit einer radikalen Wirtschaftsreform in Polen (delivered in June 1987 at the Ruhruniversität in Bochum at a conference devoted to the economic reforms being carried out in the Eastern European countries), Die Auslandsverschuldung Polens und die Moglichkeit ihres Abbaus (presented in June 1988 at an international conference on the subject of global debt and organized by Universität Bamberg), Die Wirtschaftsreform in Polen und ihre Auswirkung auf den Arbeitsmarkt (presented in July 1988 at the symposium scientifically organized by the Institut für Arbeitsmarkt-und Berufsforschung der Bundesanstalt für Arbeit in Nürnberg) and Wirtschaftsreform in Polen - Chancen für Joint Ventures (delivered in November 1989 at a scientific conference to promote the creation of joint ventures in Poland organized by Universität Bamberg mit der Industrie-und Handelskammer für Oberfranken) (Jaworowski, 1993, pp. 199-200; Polszakiewicz, 2006, p. 18).

In parallel with this extremely intense conference activity, Professor Jerzy Tomala significantly expanded his scientific achievements portfolio by numerous publications from the 1980s. In 1980, he published a study entitled Oddziaływanie państwa na rozwój gospodarczy $w$ kapitalizmie (The impact of the State on economic development in capitalism), prepared as part of the centrally-controlled research programme - The Inter-ministerial problem MR.I.28.05. In this publication, the Professor subjected the methods and measures of fiscal policy applied by the state to support economic development to an in-depth analysis (Tomala, 1980). A year later, the work Przestrzenne bariery rozwoju spoteczno-gospodarczego. Struktura przestrzenna przemystu i infrastruktura techniczna jako bariery 
wzrostu przemystu w świetle przyjętej koncepcji rozwoju gospodarczego regionu (na przykładzie województwa toruńskiego) (Spatial barriers to socio-economic development. The spatial structure of industry and technical infrastructure as barriers to industrial growth in the light of the adopted concept of economic development of the region (based on the example of the Torun province)), carried out as part of The Inter-ministerial problem MR.III.3.9.4 project, presented the economic regionalization of the then torunskie province and the results of taxonomic analysis and recommendations for the future prepared for this area, was published (Kosiedowski et al., 1981). In 1982, the Publishing House of University of Marseille published a work of Professor Jerzy Tomala entitled Aims and instruments of the Polish economic reform (Tomala, 1982). Another study entitled Ob sich was Flexibles findet? was published by Bayerische Rundschau in 1985 (Tomala, 1985b) as well as Przyczyny i skutki bezrobocia we wspótczesnym kapitalizmie (The causes and effects of unemployment in modern capitalism) (Tomala, 1985c). In 1985, the conference proceedings from the scientific session which took place in November 1983 in Torun were also published. Professor Jerzy Tomala was appointed the scientific editor of these materials which were then published in the book form and were entitled Nauka Karola Marksa a wspótczesność (Karl Marx’s science and the modern world). This publication contained primarily articles about Marx's conception of law and the foundations of Marxist humanism and controversy related to this idea, as well as considerations concerning the Marxist theory of economic crises and the relationships between the Marxist theory of social development and the Marxist political economy (Tomala, 1985a). As an increasingly recognised scholar, in 1986 Professor Jerzy Tomala was asked to write two scientific reports - one for the Ministry of Science and Higher Education, entitled Trends of socio-economic development of the underdeveloped countries and their significance for Poland and the other for the Polish Economic Society Branch in Bydgoszcz, Improving management efficiency as a condition for export development (Tomala, n.d.). Additionally, in 1989, the Higher Technical School in Brno published the work Makroekonomicke rizeni produktiva $v$ americkem hospodarstvi (Tomala, 1989).

The early 1990s was the time when the most important scientific awards were granted to Professor Jerzy Tomala. In 1990, a comprehensive study Suggestions for the formation of investment policies in the area of industrial economies in Poland was published, which was the result of close cooperation between Professor Jerzy Tomala and Professor Peter Friedrich of the University of Munich (Friedrich \& Tomala, 1990). For this work, Professor Jerzy Tomala received the first-degree award of the Rector of Nicolaus Copernicus University in Torun. An additional distinction was the fact that this study became the information base for granting investment aid to the undertakings in the field of industrial restructuring by the then European Community (Polszakiewicz, 2006, pp. 18-19). On February 12, 1991, by virtue of the decision of the Minister of National Education, Professor Jerzy Tomala was appointed as a full professor at Nicolaus Copernicus University in Torun (Tomala, n.d.). 
Further works created in the period following the appointment to a full professor include a study entitled Lessons of the privatization experience in Poland written cooperatively with Professor Martin Carnoy (Carnoy \& Tomala, 1993), a monograph Teoria polityki ekonomicznej $w$ systemie gospodarki rynkowej (Theory of economic policy in a market economy system) (on which the Professor had been working since 1988) extensive fragments of which he presented in his lectures and articles, and an essay from 1998 - Ewolucja podstaw i celów polityki ekonomicznej Stanów Zjednoczonych (Evolution of the foundations and goals of the US economic policy). In the last of the works cited, Professor Jerzy Tomala submitted a thorough, synthesizing analysis of the foundations and objectives of the macroeconomic policy of the United States of America from the 1930s to the 1990s. In this publication, he put forward the thesis that an applied economic policy concerns both shaping framework conditions for economic activity and the impact on the course of economic processes from the point of view of achieving the desired goals. In this context, he described the four basic issues of the decision-making process within economic policy, i.e. the objectives of this policy, the means to be applied, the recognition of the current and future economic situation, and control. When presenting the issue of economic policy goals in this work, Professor Jerzy Tomala emphasized in a special way the occurrence of the so-called 'bundles of goals' which are characterised by the occurrence of mutual, simultaneous connections and interactions that are complementary and conflicting in nature. In turn, in his works concerning the tools of US economic policy, the Professor focused mainly on numerous instruments of monetary, fiscal policies as well as on the most controversial policy of prices and incomes. The whole discussion was concluded with the statement that findings stemming from monitoring and analysing the effectiveness of the methods and tools used should impact making future economic decisions (Tomala, 1998, pp. 35-59).

At this point, it should be emphasized that Professor Jerzy Tomala's total academic accomplishments include more than one hundred and twenty works. These are monographs, studies, dissertations, articles, reviews, textbooks and other studies (especially informative ones and those popularizing science), including unpublished works (Tomala, n.d.).

\section{Didactic activity at Nicolaus Copernicus University in Torun}

The scientific talent, the cosmopolitan lifestyle and the name recognised in the world of economics are the unquestionable qualities of Professor Jerzy Tomala. It must be emphasised that despite the Professor's enormous engagement in research activity, he did not neglect his most important mission - didactic mission. It must be remembered that during the entire period of work at Nicolaus Copernicus University in Toruń, the Professor conducted numerous lectures and seminars dedicated to students of various faculties, majors, and specialisations. 
In the years 1969-1972, at the then Economic Institute of his Torun Alma Mater, Professor Jerzy Tomala taught classes in planning and economic policy, and in 1972 he started to lecture the political economy of capitalism to first-year students. Next, in 1980 - already at the Faculty of Economic Sciences of Nicolaus Copernicus University in Torun - he conducted a compulsory lecture on contemporary problems of economic theory and economic policy in highly developed countries, which became very popular among students, and it was not due to its obligatory nature, but because of the opportunity to get acquainted with the latest achievements of Western economic thought. Moreover, in the 1980s Professor Jerzy Tomala lectured on employment policy in highly developed countries especially to students of labour economics and social policy. An inestimable didactic value contributed by the Professor to the Faculty of Economic Sciences was a series of lectures delivered in foreign languages. In the years 1980-1984, Professor Jerzy Tomala lectured in English (Problems of economic growth policies in western countries), and then in German and English in the field of economic policy of the United States of America (Jaworowski, 1993, p. 201; 1999, p. 194; Tomala, n.d.).

Professor Jerzy Tomala conducted didactic activities also in other units of the University. In the 1970s, he lectured on the theory of economic growth and political economy at the Faculty of Law and Administration, and later taught these subjects also to students studying at the Faculty of Humanities and the Institute of Geography (Polszakiewicz, 2006, p. 19).

Also, a mention should be made that Professor Jerzy Tomala was invited to work as an academic teacher in other scientific and didactic institutions in Poland, including the Higher School of Economics in Poznan, Adam Mickiewicz University in Poznań, WUML in the cities of Poznań and Bydgoszcz and the Higher School of Economics in Bydgoszcz (operating under the auspices of the Polish Economic Society), and recently at the Higher School of Banking in Torun (Tomala, n.d.).

Professor Jerzy Tomala proved his teaching skills also abroad. In 1981 (in the summer semester) he was employed as a visiting professor at the Faculté d'Economie Appliquée l'Université d'Aix-Marseille III (The Faculty of Applied Economics at the University of Aix-Marseille III), where he gave lectures on comparative analysis of the theory and on policy of economic growth to graduate and doctoral students. In February and March 1989 he was again invited by the Faculty and as a visiting professor he lectured on East-West economic relations to graduate students of foreign trade. In addition, in 1991 (in the summer semester) Professor Jerzy Tomala went to Munich, where he worked as the Gastprofessor at the Fakultät für Wirtschafts-und Organisationswissenschaften, Universität der Bundeswehr München (The Faculty of Economics and Management at the University of the Bundeswehr in Munich). In this department he gave lectures and conducted seminars on the joint ventures processes and the system transformation in Poland (Jaworowski, 1999, p. 193; Polszakiewicz, 2006, p. 18; Tomala, n.d.). 
When writing about the didactic activity of Professor Jerzy Tomala, it needs to be underlined that educated a large group of graduates and young researchers. Among his students, the Professor gained the authority of a demanding and extremely accurate graduate thesis supervisor, mainly in the field of theory and economic policy in developed capitalist countries and analyses of development processes taking place in these countries. According to the statistics of Nicolaus Copernicus University in Torun, Professor Jerzy Tomala was the scientific supervisor of over two hundred and twenty students who obtained the title of Master of Economics. Three of his seminar students held annual internships at renowned Western universities, i.e. the University of California, the Virginia Polytechnic Institute in the State University, and the Universität Bamberg, Germany. Furthermore, Professor Jerzy Tomala promoted six doctoral students in economics and regularly reviewed post-doctoral and doctoral dissertations, including the review of a doctoral dissertation Inconvertibilité monetaire et probleme de véracité des prix en economie socialiste de l'Europe de l'Est, defended in 1981 at the Faculty of Applied Economics at the University of Aix-Marseille III. Professor Jerzy Tomala was also the promoter of honorary doctorate, granted in 1996 by the Senate of Nicolaus Copernicus University in Torun to Professor Peter Friedrich from the University of Bundeswehr in Munich (Jaworowski, 1999, pp. 193-194; 1993, pp. 200-201).

For his numerous achievements in didactics, Professor Jerzy Tomala received many awards, including an individual second-class prize awarded to him in 1976 by the Minister of Science, Higher Education and Technology, in 1982 he received the Medal of the National Education Commission and several awards of the Rector of Nicolaus Copernicus University in Torun (Tomala, n.d.). It seems, however, that in this area of activity the greatest distinctions (and perhaps the nicest for the heart of every academic teacher) were granted by the Professor's students - he gained the opinion of an outstanding scholar and respectable didactic, and even a kind of 'magician' who was revealing the iron curtain in front of them and was leading them to the world of Western economic thought. According to unofficial student notes, the first year students of the then Economic Institute of Nicolaus Copernicus University in Torun mentioned with a feeling of nostalgia a blue Opel in which the professor used to come to classes. He was then a breath of freedom for them (Jaworowski, 1999, p. 194; Karaszewski, 2004, p. 13). Students of the Faculty of Economic Sciences showed their respect to Professor Jerzy Tomala and gave very high evaluations of his classes and lectures in anonymous surveys of academic teachers and their didactic classes, during which the Professor was twice honoured for gaining the title of 'The Best Faculty Teacher' (Jaworowski \& Karaszewski, 2018, pp. 199-200). 


\section{Organizational activity conducted for Nicolaus Copernicus University}

With similar conscientiousness and great devotion and enthusiasm, Professor Jerzy Tomala devoted himself also to organizational activities performed for Nicolaus Copernicus University in Toruń. After February 1969, i.e. when he was transferred from the Higher School of Economics in Poznań to the Copernicus town, he undertook to organize together with the late Professor Jerzy Liczkowski the Economic Institute operating within the structures of the Torun Alma Mater on the rights of the faculty. In the newly established Institute, Professor Jerzy Tomala (from February 1, 1969) assumed the function of a deputy dean for didactic and educational matters and the head of the Department of Planning and Economic Policy, and then from December 1, 1974 of the head of the Department of Political Economy and History of Economic Thought. In 1976, the said Economic Institute of Nicolaus Copernicus University in Torun, by virtue of the decision of the Minister of Science, Higher Education and Technology, was transformed into the Faculty of Economic Sciences, and two institutes were created within its framework, i.e. the Institute of General Economics and the Institute of National Economy Management. In the same year, the post of the director of the former Institute was entrusted to Professor Jerzy Tomala, who held it until 1983, when the department-chair structure was restored at the Faculty of Economic Sciences. From that time until 1991, Professor Jerzy Tomala headed the Department of Political Economy and Socio-Economic Policy and the Department of Political Economy (Dolny et al., 2003, pp. 5-7; Jaworowski, 1993, p. 200).

When writing about the organizational activity of Professor Jerzy Tomala conducted for the benefit of the Faculty of Economic Sciences of Nicolaus Copernicus University in Torun, it is necessary to mention his great and long-term efforts made to obtain the consent of the Ministry of Science, Higher Education and Technology to start the construction of the new building of the Faculty. These efforts were successful and in 1985 crowned with the incorporation of the construction of the said facility into the Ministry's investment plan and the commencement of construction works in 1987. In the work on the efficient implementation of the investment, a certain role was played by the Professor's second wife ${ }^{4}$ - late Krystyna Tomala - thanks to her efforts it was easier for the building contractor to access and purchase the necessary building materials, the lack of which was the biggest barrier for the construction industry at that time in Poland (Dolny et al., 2003, p. 13; Karaszewski, 2004, p. 14).

In 1988, the Faculty of Economic Sciences of Nicolaus Copernicus University in Torun, and thus Professor Jerzy Tomala, had to face another challenge. In connection with the socio-economic changes taking place in Poland, it was necessary to undertake activities aimed at the overall transformation of the educa-

\footnotetext{
${ }^{4}$ Professor Jerzy Tomala's first wife was Janina Tomala.
} 
tion system of future economists at the Torun Alma Mater. Therefore, in the years 1989-1990, Professor Jerzy Tomala's efforts focused on helping to prepare comprehensive reforms of studies at the Faculty of Economic Sciences of Nicolaus Copernicus University in Torun and on their successive implementation from the academic year 1990/1991 onwards (Dolny et al., 2003, p. 13).

The Professor's involvement in organizational activity was quickly extended to other units of the University. In the years 1978-1981, he held the position of vice-rector for investment and development, thus being the first deputy of the Rector of Nicolaus Copernicus University in Torun. Moreover, for fifteen years he was an active member of the University Senate, participated in the meetings of the Council of the Faculty of Economic Sciences and worked for several Senate and Rector commissions. For many years, he was also a member of the Council of the Main University Library, and from 1972 he started to supervise the functioning of the Library of the Faculty of Economic Sciences at Nicolaus Copernicus University, and contributed to a significant enrichment of its collections with numerous copies of American and West German economic books. Professor Jerzy Tomala also had a great gift of establishing, tightening and permanently maintaining scientific contacts with Western universities, which in those days was something of invaluable value for every self-respecting Polish university. When conducting that activity, the professor succeeded in preparing and signing of a cooperation agreement with the University of Bamberg (Jaworowski, 1999, pp. 193-194; Tomala, n.d.).

At this point, it must also be clearly stressed that Professor Jerzy Tomala for years had been active in organizing and working for the dissemination of scientific achievements, being a distinguished member of the Polish Economic Society (whose Golden Honorary Badge he received in 1969), the Poznań Society of Friends of Science, and the Torun Scientific Society (Tomala, n.d.).

For his interesting initiatives and great achievements in the field of organizational work carried out for the University, Professor Jerzy Tomala received many awards and distinctions from university authorities, including the first-degree award of the University Rector received in 1989 as well as a special medal for merit for the development of the Faculty of Economic Sciences and Management in Torun (in 2008) that was granted to him on the occasion of the fortieth anniversary of the Faculty (Jaworowski, 1999, p. 193).

On September 30, 2004, Professor Jerzy Tomala completed his thirty-fiveyear work at Nicolaus Copernicus University in Toruń, but he maintained a lively relationship with the Faculty of Economic Sciences and Management and its employees. To express gratitude and to commemorate the ninetieth anniversary of the birth of Professor Jerzy Tomala, on April 7, 2016, an extraordinary meeting of the Council of the Faculty of Economic Sciences and Management was convened, during which the audience had the opportunity to listen to the Professor's speech, as turned out later the last one delivered at the University (Jaworowski \& Karaszewski, 2018, p. 201). Professor Jerzy Tomala passed away on December 3, 2017, at the age of ninety-one, and six days later a funeral 
Mass was celebrated in St. Joseph Church in Torun. During the funeral ceremony on December 9, 2017 at the cemetery of St. Joseph in Torun, Professor Jerzy Tomala was farewelled by his family and crowds of friends, employees and students of Nicolaus Copernicus University. In commemoration of his great scientific, didactic and organizational achievements on June 14, 2018 (as part of the Jubilee celebrations of the 50th anniversary of the existence of economic studies at Nicolaus Copernicus University in Toruń) a ceremony of unveiling the board of auditorium named after Professor Jerzy Tomala was held. Almost all of the first students of the Faculty of Economic Sciences and Management arrived to this ceremony. They were also the first students that Professor Jerzy Tomala met in Toruń (Sojak, 2018, p. 526).

\section{Conclusion}

Concluding the reflections on the person, life and activity of Professor Jerzy Tomala, one would have to say that the Polish economy, as well as the entire history of the Faculty of Economic Sciences and Management of Nicolaus Copernicus University in Toruń would lose much value, if it had not been for this Professor - an outstanding expert in the subject of economic growth and a respected academic teacher.

In his many years of work, Professor Jerzy Tomala became a scholar recognised in Poland and internationally - first and foremost as an authority in the field of broadly understood macroeconomic problems of economic growth (with particular emphasis on the impact of investment, technological progress and efficiency of technical and economic relations on the long-term growth of national income) and in the area of economic policy of developed countries, mainly of the United States of America. It should be stressed that Professor Jerzy Tomala conducted his studies based on numerous observations and analyses of empirical data, carried out directly in Western countries that were the subject of his deliberations. The professor's major research interests also included the issue of full employment, the concept of a potential national product, and educational policy. What deserves special mention is the fact that he was the first author in the Polish economic literature to assess comprehensively the famous Denison's multifactor model.

At the peak of his academic career, Professor Jerzy Tomala was invited to various study internships at prestigious universities in the United States and to renowned scientific and teaching institutions in Western Europe, where he participated in numerous scientific debates devoted to the main problems of the global economy and the role of economic education in socio-economic development. He also worked at those universities as a visiting professor. The Professor was active in the international scientific community and extended cooperation with Western European universities, in particular with the universities in Aix-en-Provence, Bamberg, Bochum, Munich, and Oldenburg. He was also a consultant of the World Bank, and the findings contained in his publica- 
tions were considered before making some important decisions by such international organizations as OECD, the European Community, or the World Bank.

Professor Jerzy Tomala could boast of a very rich portfolio of scientific accomplishments (over one hundred and twenty works). Among the books, articles, reviews, scripts, and other works published by him, four items deserve special mention, namely his doctoral dissertation Relacje kapitatowe $w$ teorii wzrostu gospodarczego (Capital Relations in the theory of economic growth) (published in 1963 and awarded with the third level academic award of the Minister of Higher Education and later translated into the Czech language for internal needs of the Institute of Economics, the Czechoslovakian Academy of Sciences), postdoctoral thesis Podstawy polityki wzrostu gospodarczego Stanów Zjednoczonych Ameryki Pótnocnej (Fundamentals of economic growth policy of the United States of America) (published in 1968, and a year later awarded with the third-level scientific award of the Minister of Education and Higher Education and cited by the OECD when taking a stance on the counter-cyclical policy), the work Access to higher education in Poland under the aspects of social equality and economic development (authored by Professor Jerzy Tomala, Zbigniew Kwieciński and Ryszard Borowski, published in 1976 as part of the World Bank study on the role of education in economic development) and a study entitled Suggestions for the formation of investment in the area of industrial economies in Poland (the result of a close cooperation with Professor Peter Friedrich of the University of Munich, issued in 1990 and awarded with the first degree award of the Rector of Nicolaus Copernicus University in Torun. The study was later used as an information base when deciding on granting Poland investment aid for undertakings in the field of industrial restructuring by the then European Commonwealth). At this point, it is worthwhile to quote the opinion of Professor Wacław Wilczyński who said that 'all of the publications of Jerzy Tomala are characterized by the ambition of showing something new, not something exiguous's. The Professor achieved considerable successes in the field of didactics and organizational activity. Almost from the very beginning, he participated in the creation of the Institute of Economics at Nicolaus Copernicus University in Torun. The Institute was transformed in 1976 into the Faculty of Economic Sciences, and from 1993 it was functioning under the name of the Faculty of Economic Sciences and Management. At this Faculty, Professor Jerzy Tomala educated a large group of students, graduates, and young researchers. Altogether over two hundred and twenty of his seminar students obtained a master's degree in economics. In addition, he promoted six doctors of economic sciences and promoted honorary doctorate granted by the Senate of Nicolaus Copernicus University in Torun to Professor Peter Friedrich from the University of the Bundeswehr in Munich.

For his accomplishments in the field of science, didactics and organizational work, Professor Jerzy Tomala received high state awards, prestigious awards

5 The full text of the opinion of Professor Wacław Wilczyński about Professor Jerzy Tomala can be found in Tomala (n.d.). 
of the Minister of Higher Education and of the Rector of Nicolaus Copernicus University in Torun, as well as numerous honours from his students and alumni.

\section{References}

Carnoy, M., \& Tomala, J. (1993). Lessons of the privatization experience in Poland. Stanford: Stanford University.

Dąbrowski, Z., Kruszczyński, S., Tomala, J., \& Winiarski, B. (1961). Polityka ekonomiczna i planowanie gospodarki narodowej. Skrypty Uczelniane Wyższej Szkoty Ekonomicznej w Poznaniu, 16.

Dąbrowski, Z., Kruszczyński, S., Tomala, J., \& Winiarski, B. (1962). Polityka ekonomiczna i planowanie gospodarki narodowej. Skrypty Uczelniane Wyższej Szkoty Ekonomicznej w Poznaniu, 23.

Dąbrowski, Z., Kruszczyński, S., Tomala, J., \& Winiarski, B. (1965). Polityka ekonomiczna i planowanie gospodarki narodowej. Skrypty Uczelniane Wyższej Szkoty Ekonomicznej w Poznaniu, 49.

Dąbrowski, Z., Kruszczyński, S., Tomala, J., \& Winiarski, B. (1966). Polityka ekonomiczna i planowanie gospodarki narodowej. Skrypty Uczelniane Wyższej Szkoty Ekonomicznej w Poznaniu, 37.

Dolny, E., Szczepańska, E., Rybińska, M., Zawadzka, K., \& Haffer, M. (2003). Wydziat Nauk Ekonomicznych i Zarządzania Uniwersytetu Mikotaja Kopernika w Toruniu 1968-2003. Toruń: ateFOKA.

Friedrich, P., \& Tomala, J. (1990). Suggestions for the formation of investment policies in the area of industrial economies in Poland. Brussels: Commission of the European Communities, Division for International Industrial Relations.

Jaworowski, P. (1999). Wydziat Nauk Ekonomicznych i Zarządzania Uniwersytetu Mikotaja Kopernika w Toruniu u progu XXI wieku. Toruń: Wydawnictwo Uniwersytetu Mikołaja Kopernika.

Jaworowski, P. (Ed.). (1993). Wydziat Nauk Ekonomicznych i Zarządzania Uniwersytetu Mikotaja Kopernika w Toruniu 1968-1993. Toruń: Wydawnictwo Uniwersytetu Mikołaja Kopernika.

Jaworowski, P., \& Karaszewski, W. (Eds.). (2018). Wydziat Nauk Ekonomicznych iZarządzania 1968-2018: wspomnienia. Toruń: Wydawnictwo Naukowe Uniwersytetu Mikołaja Kopernika.

Karaszewski, W. (2004). Słowo o Profesorze. In M. Haffer, \& W. Karaszewski (Eds.), Czynniki wzrostu gospodarczego. Toruń: Wydawnictwo Uniwersytetu Mikołaja Kopernika.

Kosiedowski, W., Popławski, W., \& Tomala, J. (1981). Przestrzenne bariery rozwoju spoteczno-gospodarczego. Struktura przestrzenna przemystu i infrastruktura techniczna jako bariery wzrostu przemystu w świetle przyjętej koncepcji rozwoju gospodarczego regionu (na przyktadzie województwa toruńskiego). Toruń.

Kruszczyński, S., Tomala, J., \& Wojtasiewicz, L. (1970). Polityka ekonomiczna i planowanie gospodarki narodowej. Skrypty Uczelniane Wyższej Szkoty Ekonomicznej w Poznaniu, 106. 
Polszakiewicz, B. (2006). Jubilat Profesor Jerzy Tomala. In B. Polszakiewicz, \& J. Boehlke (Eds.), Ead instytucjonalny $w$ gospodarce. Toruń: Wydawnictwo Uniwersytetu Mikołaja Kopernika.

Sojak, S. (Ed.) (2018). Wydziat Nauk Ekonomicznych i Zarządzania 1968-2018: wizerunek naukowy i dydaktyczny. Toruń: Wydawnictwo Naukowe Uniwersytetu Mikołaja Kopernika.

Tomala, J. (1954a). Znaczenie i drogi wzrostu wydajności pracy. Gazeta Poznańska, 22, 26, 28-29.01.1954.

Tomala, J. (1954b). Znaczenie lepszego wykorzystania zdolności produkcyjnych przedsiębiorstw dla wzrostu dobrobytu społeczeństwa. Gazeta Poznańska, 4-5.02.1954.

Tomala, J. (1955). Bilans dziesięciolecia budownictwa pokojowej gospodarki na terenie Niemieckiej Republiki Demokratycznej (1945-1955). Przegląd Zachodni, 7-8.

Tomala, J. (1956). O proporcjach w rozwoju produkcji przemysłowej w Niemieckiej Republice Demokratycznej. Przegląd Zachodni, 9-10.

Tomala, J. (1957). Tempo rozwoju produkcji przemystowej w Niemieckiej Republice Demokratycznej. Poznań: Instytut Zachodni.

Tomala, J. (1960). Technologiczne parametry wzrostu produkcji. Ruch Prawniczy, Ekonomiczny i Socjologiczny, 4.

Tomala, J. (196la). (Rev.). Istota i rodzaje postępu technicznego. Rocznik Ekonomiczny PTE Oddziat w Poznaniu 1960.

Tomala, J. (1961b). Kwantyfikacja wpływu zmian zatrudnienia i wydajności pracy na proces wzrostu gospodarczego. Ruch Prawniczy, Ekonomiczny i Socjologiczny, 4.

Tomala, J. (1962a). Długofalowy trend współczynnika kapitału. Ekonomista, 6.

Tomala, J. (1962b). Koncepcja równowagi dynamicznej w modelach wzrostu typu Harrod-Domar. Zeszyty Naukowe Wyższej Szkoty Ekonomicznej w Poznaпiu, 7.

Tomala, J. (1962c). O przyspieszeniu, inwestycjach indukowanych i autonomicznych. Ruch Prawniczy, Ekonomiczny i Socjologiczny, 2.

Tomala, J. (1962d). Postęp techniczny i wzrost gospodarczy. Ekonomista, l.

Tomala, J. (1963). Relacje kapitatowe $w$ teorii wzrostu gospodarczego. Warszawa: Państwowe Wydawnictwo Naukowe.

Tomala, J. (1964). (Rev.). Postęp techniczny a wydajność pracy w przemyśle. Ekonomista, 3.

Tomala, J. (1966). Dyskusja. In S. Kruszczyński (Ed.), Węztowe problemy ekonomicznego rozwoju Wielkopolski 1945-1965. Poznań: Państwowe Wydawnictwo Naukowe.

Tomala, J. (1968). Podstawy polityki wzrostu gospodarczego Stanów Zjednoczonych Ameryki Północnej. Zeszyty Naukowe Wyższej Szkoły Ekonomicznej w Poznaniu, 41.

Tomala, J. (1970a). (Rev.). Postęp ekonomiczny w gospodarce przemysłowej. Ruch Prawniczy, Ekonomiczny i Socjologiczny, 4. 
Tomala, J. (1970b). Trzydziestolecie pracy naukowej prof. dr. Seweryna Kruszczyńskiego. Rocznik Wyższej Szkoty Ekonomicznej w Poznaniu.

Tomala, J. (1975a). Analityczno-instrumentalna rola potencjalnego produktu narodowego. Ekonomista, 6.

Tomala, J. (1975b). Analiza kapitalistycznego systemu oświaty i jego roli w rozwoju społeczno-gospodarczym. Ekonomista, 4.

Tomala, J. (1975c). Interpretacja pełnego zatrudnienia w powojennej polityce ekonomicznej Stanów Zjednoczonych. Acta Universitatis Nicolai Copernici. Ekonomia, 72.

Tomala, J. (1980). Oddziaływanie państwa na rozwój gospodarczy w kapitalizmie. Biuletyn Informacyjny Zespołu Koordynacyjnego Problemu Międzyresortowego „Podstawy Przestrzennego Zagospodarowania Kraju”, 25.

Tomala, J. (1982). Aims and instruments of the Polish economic reform. Marsylia: Université d'Aix-Marseille.

Tomala, J. (1985b). Ob sich was flexibles findet? Bayerische Rundschau, 98.

Tomala, J. (1985c). Przyczyny i skutki bezrobocia we wspótczesnym kapitalizmie. Bydgoszcz: ANS Bydgoszcz.

Tomala, J. (1989). Makroekonomicke rizeni produktiva $v$ americkem hospodarstvi. Brno: Wydawnictwo Wyższej Szkoły Technicznej w Brnie.

Tomala, J. (1998). Ewolucja podstaw i celów polityki ekonomicznej Stanów Zjednoczonych. In J. Tarajkowski (Ed.), Problemy polityki ekonomicznej. Studia i szkice na jubileusz Profesora Zdzistawa Dąbrowskiego. Poznań: Wydawnictwo Akademii Ekonomicznej w Poznaniu.

Tomala, J. (Ed.). (1985a). Nauka Karola Marksa a wspótczesność: materiaty z sesji naukowej. Toruń: Wydawnictwo Uniwersytetu Mikołaja Kopernika.

Tomala, J. (n.d.). Personal files of Professor Jerzy Tomala (file K-101/49). Archives of Nicolaus Copernicus University in Toruń, Poland.

Tomala, J., Kwieciński, Z., \& Borowicz, R. (1976). The access to higher schools in Poland in the aspect of social equality and economic development. Toruń: Nicolaus Copernicus University Press.

\section{Acknowledgements}

Author contributions: the author has given an approval to the final version of the article.

Funding: this research was funded by the author's own resources. 